\title{
Protecting Coastal Habitats and Enhancing Fisheries Resources Using Big Size Artificial Reefs in the East Coast of Peninsular Malaysia
}

\author{
${ }^{1}$ Ahmad Ali, ${ }^{2}$ Mohamed Pauzi Abdullah, ${ }^{3}$ Rafezi Hazizi, ${ }^{3}$ Abdul Halim Marzuki, ${ }^{1}$ Raja Bidin Raja \\ Hassan \\ ${ }^{1}$ SEAFDEC/MFRDMD, 21080 Chendering Terengganu. \\ ${ }^{2}$ Fisheries Research Institute, Batu Maung, 11960 Penang, Malaysia. \\ ${ }^{3}$ Engineering Division, Department of Fisheries Malaysia, Level 4, Podium 2, Block 4G2, Presint 4 Putrajaya, Malaysia. \\ *aaseafdec@seafdec.org.my(Corresponding Author)
}

\begin{abstract}
Artificial reefs (ARs) program in the east coast of Peninsular Malaysia commenced in 1979 with the objective to promote and establish fish sanctuaries, enhance coastal fisheries resources and deter the encroachment of prohibited inshore areas by trawlers. The program initially started off with the utilization of discarded materials such as tyres and derelict wooden boats. However, in 2006, the Department of Fisheries Malaysia (DoFM) made a major policy change in terms of choice and design of construction material by opting for large and robust reinforced concrete ARs. The newly designed ARs took into consideration the biotic and abiotic factors such as the fish behavior, targeted species, physical oceanography and marine engineering cogitations. The ARs were built according to the British Standard 8110. By the end of 2010, a total of 15 newly designed ARs weighing between 5-42 metric tons/ module and measuring between 1.6-3.85m (length, width and height) were produced and nine of them were deployed in the East Coast of Peninsular Malaysia. Those ARs have by now developed into new habitats not only for fish, but also for other marine flora and fauna. At least 76 commercial and 33 coral fish species were recorded near or within the AR structures. The ARs are also functioning effectively as hindrance to illegal trawling. This paper reports on the progress of the research and development (R\&D) of the big size ARs program implemented in the East Coast of Peninsular Malaysia within the 2006-2012 period.
\end{abstract}

(Keywords: big size artificial reefs, Malaysia)

\section{INTRODUCTION}

In Malaysia, artificial reefs (ARs) are referred to as any man-made structures or natural objects placed in marine water body to provide new habitat for fish and other flora and fauna, and at the same time prevent the encroachment of destructive gears such as trawls into protected areas. Some researchers like [1] conclude that artificial reefs either aggregate existing scattered fish or allow secondary biomass production through increased survival and growth of new individuals as a result of the shelter and food resource provided by ARs . However, [2] and [3] reported that the high densities of fouling, sessile and encrusting organisms on AR structures can be a major source of food supply for fishes.

The main reason for the deployment of ARs by the Department of Fisheries Malaysia (DoFM) since 1975 was due to stock decline in the coastal waters [4]. The coastal areas of the east coast of Peninsular Malaysia, namely Kelantan, Terengganu, Pahang and East Johor have also been intensively exploited by trawlers since the introduction of the bottom trawl net in 1967. Information on the declining coastal fishery resources was obtained from a series of surveys conducted by the DoFM. Results from the first trawl survey, in 1967, which encompassed the coastal area from Kelantan to the southern part of East Johor within five nautical miles from coastline, showed that the average catch rate was $428 \mathrm{~kg} / \mathrm{hr}$ [5]. A repeat survey conducted in 1979 in the same area recorded that the average catch rate had increased to $516 \mathrm{~kg} / \mathrm{hr}$ [6] but drastically decreased to only $167 \mathrm{~kg} / \mathrm{hr}$ in 1971 [7]. However, the survey conducted in 1972, showed an average catch rate that had increased to $255 \mathrm{~kg} / \mathrm{hr}$ [8] but decreased to $238 \mathrm{~kg} /$ hr in 1974 [9].

Construction and deployment of ARs was one of management measures taken by the DoFM in order to rejuvenate the depleting coastal fishery resources. It would also curb encroachment of trawlers, reduce conflict between commercial and traditional fishers 
and also increase opportunities for small-scale fisherfolk to improve their livelihood from fishing [10]. AR sites in the east coast of Peninsular Malaysia were first established on 26 May 1978 near Pisang Island in Johor using discarded tyres, followed by near Ekor Tebu Island in Terengganu on 22 June 1979, Tumpat in Kelantan on 23 July 1983 and near Kuala Rompin in Pahang on 24 March 1984. Until 1993, more than three million tyres have been used to make ARs in Malaysia and 60\% of them were deployed in the east coast of Peninsular Malaysia [11].

However, after 1995, tyres were forbidden due to complaints by many parties that automobile tyres are leaching toxins into the marine environment. In 2007 and 2008 [12], conducted acoustic surveys using side scan sonar to map the locations of ARs in Terengganu waters found that almost all tyre ARs deployed on the open sea floor since 1979 were blighted by strong current and most of them were submerged under the sea bottom. All ARs using derelict wooden boats were also disintegrated and only the engine parts remained attached to the hull. Some tyre ARs sites located between the islands were still in good condition but poorly colonized with few marine life and attracted merely small fish assemblages. However, ARs constructed using reinforced concrete either deployed on open area or closed to the islands are thriving and maintaining good condition.

Experience and knowledge gained since 1975 were then used to advantage for better planning and management of ARs program during the Ninth Malaysia Plan (20062010) and the ARs program was implemented in the whole country for the first time using federal and state funds amounting RM32,004,162. For the states in the east cost of Peninsular Malaysia (Kelantan, Terengganu, Pahang and Johor), total funds received amounting RM 13.8 million. Kelantan received RM 2.1 million, Terengganu (RM8.9 million), Pahang (RM1.9 million) and Johor (RM 0.9 million). It became the highest budget received by the DoFM since the ARs program started in 1975 [13]. This paper reports the outcomes of research undertaken to investigate the effectiveness of big size ARs in protecting coastal habitats from illegal trawlers.

\section{OBJECTIVES}

The objectives of this study were to design and construct new ARs which can curb the encroachment of traditional fishing areas by illegal fishing gears especially trawls, provide firm substrate for marine fauna and flora to grow on, and to increase fishery resources in the coastal area.

\section{MATERIAL AND METHODS}

\section{Study sites}

The study was conducted at four states in the east coast of Peninsular Malaysia namely Kelantan, Terengganu, Pahang and East Johor. Site selections were conducted prior to deployment. Site surveys were carried out using echo-sounders to determine the seabed topography, Smith McIntyre grab for sediment collection and current meter for harnessing information on direction and speed of current. Consultations with local fishers were also conducted to compile information on fishery resources at the proposed sites. The selected sites were located between four to five nautical miles from the coast line. The types of ARs deployed in each state are as shown in Figure 1.

\section{Specification of artificial reefs modules}

The focus was to construct big size ARs using durable materials which can deter the encroachment of unfriendly fishing gears especially trawlers into traditional fishing ground and marine protected areas, provide substrate for marine fauna and flora to grow, and provide new habitat for adult and juvenile fishes. The initial sketch was provided by researchers from Research Division of the DoFM based on their knowledge and experiences in fish behavior, marine engineering, physical oceanography and target species. Final and detailed technical drawings were prepared by Engineering Division of the DoFM. Until 2010, 15 new designs were constructed. Each module measured between 1.65-3.85 $\mathrm{m}$ in length, width and height and weighed between 5-42 metric tonnes. There were soft bottom ARs (five designs), recreational ARs (two designs), cube ARs (two designs), cuboid ARs (three designs), lobster ARs (two designs) and tetrapod ARs (one design). Nine of these designs (Figure 2-a-Figure 2-i) were constructed and deployed in the east coast of Peninsular Malaysia. The specification of these designs are as shown in Table 1. The construction work followed the British Standard 8110 which stipulated concrete cover of at least $50 \mathrm{~mm}$ thick, column and beam using four Y12 rods, for link using R8 @ 200mm c/c and slab reinforcement using BRC A10. Ready-mixed concrete grade 40-50 from batching plant was used. Cube tests were conducted after seven and 28 days of construction at the government and private laboratories. Curing was implemented for at least 28 days before deployment. Any module which did not meet the specifications stated in the tender document was rejected. 


\section{Deployment}

A pontoon or barge was used to transport the ARs from jetty to deployment sites. During the installation processes, free fall deployment method was applied using 50-80 metric tonnes crane equipped with special mechanical release device. At each site, 14-128 modules were placed two to five meters apart from each other. For the purpose of deterring illegal trawlers, some modules were placed randomly over a larger area and spaced at about 100-200 m from each other. Location of every module was recorded using Global Positioning System (GPS). Soon after deployment was completed at each site, divers were dispatched to inspect and record the condition and position of the modules on the sea bed.

\section{Reef Monitoring}

A total of 39 new sites were established from 20062010. Owing to budget constraints, underwater visual observation frequency at each site was conducted between one to five times. Visual observation was first conducted after all AR modules were deployed. Scheduled monitoring at 6, 12, 18 and 24 months after deployment was only accomplished for three cuboid ARs sites, specifically Setiu, Kuala Terengganu and Marang in Terengganu (Figure 3). Each site was placed with 128 modules of cuboid ARs.

Visual observation was conducted using close-up and wide angle video and camera images to record physical stability of the reef modules, bio-fouling and encrustation of sessile organisms, fish behavior especially with regard to their interaction with the ARs as well as fish species. Four modules were used as sampling units at each site for observation on fouling and encrusting organisms on the ARs surface. Six divers equipped with two video and two still photo cameras were dispatched to execute the monitoring assignments during each scheduled dive. Angling using hook and lines was also applied to catch fish for taxonomy and biological studies. Data on individual length and weight were recorded. Information on the effectiveness of ARs to deter illegal trawlers and fish species caught at ARs sites were also gathered from face-to-face interviews using a structured questionnaire with 323 respondents at 20 landing sites in Kelantan, 16 sites in Terengganu, five sites in Pahang and seven sites in Johor.

The number of fish /module was quantified by estimation and direct visual counting by divers and from video grabs and still pictures. Since no single method may yield a faunal assessment that is clearly more accurate or precise than others, fish aggregations and fish species associated with the ARs were assessed using a combination of several methodologies. This included non-destructive visual observation via transect, fixed stationary points as well as search pattern for fishes as recommended by [14], [15] and [16]. When the number of fish was small (less than 20 tails) such as groupers, rabbit fish, snappers, crabs and lobsters, the total count was made by divers. For large population especially of Lutjanus lutjanus, Lutjanus vitta, Atule mate and Alepes djedaba, the number of fish /module was estimated as suggested by [15]. Fish species were confirmed based on references made to [17], [18], [19], [20], [21] and [22]. Other flora and fauna species were referred to [23], [24] and [25]. Other flora and fauna species were referred to [23], [24] and [25].

\section{RESULTS AND DISCUSSION}

\section{Marine fouling, sessile and encrusting organisms}

The surface area of most ARs was colonized by sessile and encrusting organisms within six months after deployment. This was especially so for ARs placed on sandy seabed in Terengganu. Images from video and digital cameras showed almost all surfaces of ARs were covered by barnacles, molluscs, ascidians and several species of soft corals and sponges. Many species could not be precisely identified and most organisms were only identified up to genus level, because specimens were only briefly examined in situ (non-destructive visual observation) or visually from captured video and photos.

Barnacles (Balanus sp.) were found to be the most successful early colonizer of ARs surfaces. These barnacles are essentially the pioneer colonizers that eventually ceded their dominant position to other fouling organisms through succession [26]. The raw ARs surfaces that is colonized early by barnacles is primed or made suitable for other sessile organisms to settle and establish their colonies. The successor organisms are usually corals, octo-corals, sponges, ascidians and molluscs. Gorgonian sea fans, soft corals and sea whips are octocorals, and they came as late colonizers. With the abundance of these late comers, the ARs could then be regarded as having attained maturity and new habitat created. The percentage area covered by these organisms is as given in Table 2 .

Sponges (Callyspongia sp., Plakortis sp., Haliclona sp., Callyspongia sp. and Pseudoceratina sp.) barnacles, 
ascidians, pearls oyster (Pinctada spp. and Pteria spp.) colonized almost all of the surface of AR modules within six months. Soft corals such as Dendronephthya sp., Acalycigorgia sp., Scleronephthya sp. and Acabarisa sp.; sea fan (Subergorgia sp., Melithaea sp. and Rumphella sp.); sea ferns (Macrorhynchia philippina and Gymnangium gracilicaule); spiky sea pen (Scytalium sp.), wire coral (Cirripathes sp.) were among the common fauna found on the AR modules after 12 months. Other faunas such as sea cucumber (Stichopus cf horrens, Stichopus ocellatus, Opheodesoma spectabilis, Holothuria pardalis, Holothuria ocellata, Bohadschia marmorata and Euapta sp.), brittle star, crinoids, sea anemones, sea snake, crabs, shrimp, nudibranch, gastropods, tube worm and sea urchin are also recorded near or on the ARs modules. The seagrass Halophila ovalis was also found to grow near ARs site in Terengganu. The common living creatures attached or present on or near the ARs modules at three sites in Terengganu throughout the 24- month survey are shown in Appendix 1.

\section{Fish community}

Initial fish colonization pattern at ARs structure is currently unknown, because monitoring was only conducted six months after deployment. Monitoring data after six month to 45 months of deployment, revealed that ARs were effective in attracting and aggregating myriad species of fishes. Aggregation of demersal fishes which were classified as resident species such as groupers, snappers and coral fishes was mostly confined within or in close affinity to the ARs structures. Coral fishes were dominated by species from family Apogonidae. Large numbers of Apogon spp. were found schooling close to the modules and also occupying the top parts and holes of ARs. However, pelagic species preferred to swim in the middle and upper part of the ARs. These were species such as Atule mate, Alepes djedaba, Carangoides spp. and Caranx sexfasciatus which were classified as visiting species. These fishes were frequently observed to swim at mid-water and a distance away from the ARs as compared to the resident species. In all, 109 species representing 40 families of fish, crab and lobster were recorded. These included 76 commercial fishes and 33 coral fishes. The list of fishes, crabs and lobsters recorded during the study is as shown in Appendix 2.

Data from visual observation at three sampling sites in Terengganu namely Setiu, Kuala Terengganu and Marang showed 19 commercial species. The study was conducted 11-15 months after deployment for the first phase and 36-45 months after deployment for the second phase. The most dominant and economically important species throughout the study period were the big eye snapper (Lutjanus lutjanus), brown stripe snapper (Lutjanus vitta), brown barred grouper (Cephalopholis boenack), areolated grouper (Epinephelus areolotus) and painted sweetlips (Diagramma pictum). All these species were classified as resident species. The number of fish per module ranged from 300-2000 for bigeye snapper, 50-200 for brown stripe snapper, 3-8 for brown-barred grouper, 2-6 for areolated grouper and 1-30 for painted sweetlips. In general, the number of commercial fish per module ranged from 368 - 2734. The highest number per module was recorded at ARs deployed in Kuala Terengganu (1715-2784), followed by Marang (786-1587) and Setiu (368-584). Diversity of commercial fish was highest in Kuala Terengganu with 13-14 species followed by Marang (10-12 species) and Setiu (7-11 species). The details are as shown in Table 3. The area has also become a breeding and nursery ground for some demersal species especially Lutjanus lutjanus and Lutjanus vitta. This is evident from the presence of both fully gravid and juvenile individuals of these species caught by hook and line during the study period. Gravid lobsters were also found under ARs structures in Marang.

\section{Protecting coastal habitat}

Beside increasing biomass of fishes, AR modules were also designed for the protection of coastal habitats from illegal trawls. These ARs were very heavy (5-32 metric tons/module) and some were fixed with deterrent arms. The ARs were proven to be excellent tools in hindering encroachment of illegal trawlers. The testimonies left behind were their losses in terms of torn nets and entangled cod ends on almost all AR sites in Kelantan, Terengganu and Pahang. This will reduce or eliminate pressures on some ecosystems thereby allowing them the opportunity to recover naturally. The face to face interview with fishermen revealed 39\% respondents stating reduced encroachment of illegal trawlers after ARs deployment while $23 \%$ respondents states no change.

\section{Reef stability}

Most ARs modules placed on coarse sand seabed were stable and no scouring occurred. The AR design allowed the passage flow of current above the module base, thus facilitating current flow with little resistance across the 
module at the bottom. However, on softer sea bed, these ARs modules placed on sandy-mud area sank by mere $30-45 \mathrm{~cm}$ over 12 months. Such cases were observed in Kelantan and Johor. Nevertheless, the modules remained upright and not overturned.

\section{CONCLUSION}

In general, the artificial reefs program has achieved its objectives in deterring illegal trawling and increasing fishery resources in the coastal area. The most suitable material is reinforced concrete. The larger size ARs, are superior to the smaller ones in attracting more marine flora and fauna. The large size designs are excellent in performing the dual functions of creating new habitats and deterring the encroachment of trawlers into inshore areas.

We are continuing in our endeavor to seek new designs of ARs that will be able to closely imitate the natural reef. The ARs that is sought is one that is as natural as possible, capable of not only providing protection to young/ juveniles of marine fishes but also the various microhabitats for a host of other marine organisms. Appropriate physical characteristics of the AR module such as size and design do influence the success of ARs apart from their deployment in suitable locations.

\section{ACKNOWLEDGEMENT}

This research was funded by the Department of Fisheries Malaysia and State Government of Terengganu. The authors would like to express their gratitude to the Director General of fisheries Malaysia, YH Dato' Ahamad Sabki bin Mahmood, Chief of SEAFDEC/ MFRDMD Ms. Mahyam binti Mohd Isa, Director of Research Mr. Rosly bin Hassan and Mr. Ahmad Tarmidzi bin Ramly Director of Engineering Division of DoFM for their endless support of this project.

\section{REFERENCES}

1. Bohnsack, J.A. and Sutherland, D.L. (1985). Artificial reef research. A view with recommendations for future priorities. Bull. of Mar. Sci. 37 (1): 11-39

2. Woohhead, P.M.J. and Jacobson, M.E. (1985). Epifauna settlement, the process of community development and succession over two years on an artificial reef in New York Bight. Bull of Mar Sci. 37 (1): 364-376

3. Carter, J.W., Carpenter, A.L., Foster, M.s. and Jessee, W.N. (1985). Benthic succession on an artificial reef designed to support a kelp-reef commnuty. Bull. of Mar. Sci. 37 (1): 86-113

4. Wong, F.H. (1981). Construction of artificial reefs in Malaysia (In Malay). Berita Nelayan. Bil 27. December 1981: pp.16-19

5. Department of Fisheries Malaysia, (1967). Results of the joint Thai-Malaysia-Germany trawling survey off the east coast of the Malay Peninsular 1967. Prepared by the Marine Fisheries Laboratory, Department of Fisheries, Ministry of Agriculture, Bangkok, Thailand and the Fisheries Research Institute, Fisheries Division, Ministry of Agriculture and Cooperative Malaysia. Kuala Lumpur. $64 \mathrm{pp}$

6. Pathansali, D., G. Rauck, A. A. Jothy, Mohd. Shaari, S.A. and Curtin, T. B. (1974). Demersal fish resources in Malaysia waters (Trawl survey of the coastal waters off the East Coast of West Malaysia). Ministry of Agriculture and Fisheries, Malaysia. Kuala Lumpur. 46 pp

7. Jothy, A.A., Rauck, G., Mohd. Shaari, S. A. L., Ong, K. S., Liong, P. C. and Carvalho, J.L. (1975). Demersal fish resources in Malaysian waters. Second trawl survey of the coastal water off the east coast of Peninsular Malaysia (MarchMay 1971). Ministry of Agriculture and Rural Develoment, Malaysia. Kuala Lumpur. 36 pp

8. Chang, L.W., W. Weber., Kean, L. E., Ong, K. S. and Liong, P.C. (1975). Demersal fish resources in Malaysia waters. $3^{\text {rd }}$ east coast trawl survey off the east coast of Peninsular Malaysia. $14^{\text {th }}$ August $-20^{\text {th }}$ September 1972. Ministry of Agriculture and Rural Development, Malaysia. Kuala Lumpur. 19 pp

9. Lamp, F. and Mohammed Shaari, S.A.L. (1976). Demersal fish resources in Malaysian waters. Fourth trawl survey of the coastal waters off the east coast of Peninsular Malaysia $\left(13^{\text {th }}\right.$ July $-12^{\text {th }}$ August 1974. Ministry of Agriculture Malaysia. Kuala Lumpur. 25 pp

10. Jothy, A. A. (1982). A step towards alleviating the problem of declining fish resources in Malaysian coastal waters. In: Ong, K. S. and Jothy, A.A. (eds): Our seas in perspective. Malaysia Society of Marine Science, Serdang, Malaysia 5-6 August 1978: pp.77-82

11. Sukarno, W., Raja Mohammad Noordin, R.O. dan Che Omar, M.H. (1991). Assement of artificial reefs in Terengganu (In Malay). In: Proceedings 
of the Fisheries Research Seminar 1991, Gelugur Pulau Pinang: pp. 418-428

12. Ahmad, A., Mahyam, Mohd. I., Zaidnuddin, I., Mohamed Pauzi, A., Ku Kassim, K.Y., and Nor Azman, Z. (2008). Status of Artificial Reefs in Terengganu based on Images from Side Scan Sonar (In Malay). DPPSPM-SEAFDEC, Kuala Terengganu, Terengganu.

13. Ahmad, A., Maznah, O., Mohammed Pauzi, O., Rafezi, H., and Raja Bidin, R. H. (2012) (Eds). Achievement in Research and Development of Artificial Reefs, 2006-2010(In Malay), Department of Fisheries Malaysia, Putrajaya.

14. Tessier, E., Chabanet, P., Pothin, K., Soria, M., and Lasserre, D. (2005). Visual censuses of tropical fish aggregation on artificial reefs: Slate versus video recording techniques. Jour. of Exp. Mar. Bio. and Eco. 315: 17-30

15. Stephen, A. B., M. A. Samiilys, and Patrice, F. (2000). Fish and macroinvertebrate evaluation methods. In: Seaman, W. Jr. (ed): Artificial Reef Evaluation with Application to Natural Marine Habitats: CRC Press LCC. Florida: pp. 127-164

16. Bombace, G., Fabi, G., Fiorantini, L. (2000). Artificial Reefs in the Adriatic Sea. In: Jensen, A.C., Collins, K.J., Lockwood, A.P.M. (eds). Artificial Reefs in European Seas. Kluwer Academic Publishers, Great Britain: pp. 31-63

17. Allen, G., and Swainston, R. (1988). The Marine Fishes of North-western Australia. Western Australian Museum.

18. Allen, G. (2002). Marine Fishes of Tropical Australia and Southeast Asia. Western Australian Museum.

19. Anderson, R.C. 2005. Reef Fishes of the Maldives. Maldives Natural History. Vol. 1. Reef Fishes. Manta Marine.

20. Annie, P.K. Lim, Albert, C.G., (2009). Field Guide to Marine \& Estuarine Fishes of Sarawak. Fisheries Research Institute, Kuching, Sarawak. Malaysia.

21. Kuiter, H.R. (2002). Photo Guide to Fishes of the Maldives. Atoll Editions.

22. Masuda, H., and Allen, R.G. 1987. Sea fishes of the World (Indo-Pacific Region. Yama-Kei Publishers Co. Ltd. Japan.

23. Coleman, N. (2000). Marine Life of the Maldives. Atoll Editions.

24. Lin, H.S. (1992). Coral Reefs of Malaysia. Tropical Press Sdn. Bhd. Kuala Lumpur Malaysia.

25. Colin, L. P. (1978). Marine Invertebrates and Plants of the Living Reef. T.F.H. Publications, Inc. Ltd.
26. Farrell, T.M. (1991). Models and mechanisms of succession: An example from a rocky intertidal community. Ecological Monographs, 61 (1): 95-113 


\section{Type of ARs in Respective States}

\section{(2006-2012)}

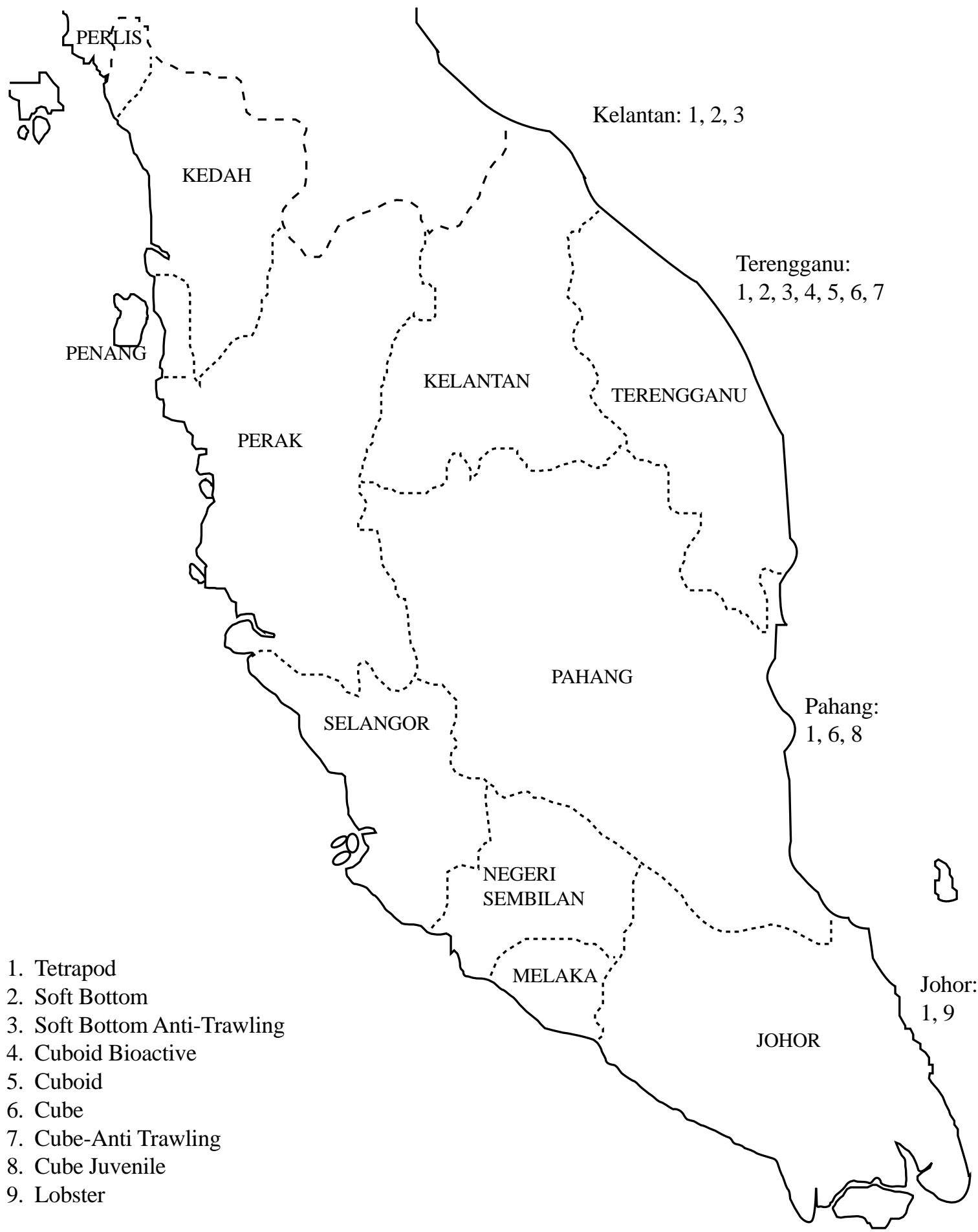

Figure 1. Types of artificial reefs deployed in the states of Kelantan, Terengganu, Pahang and Johor from 2006-2012 


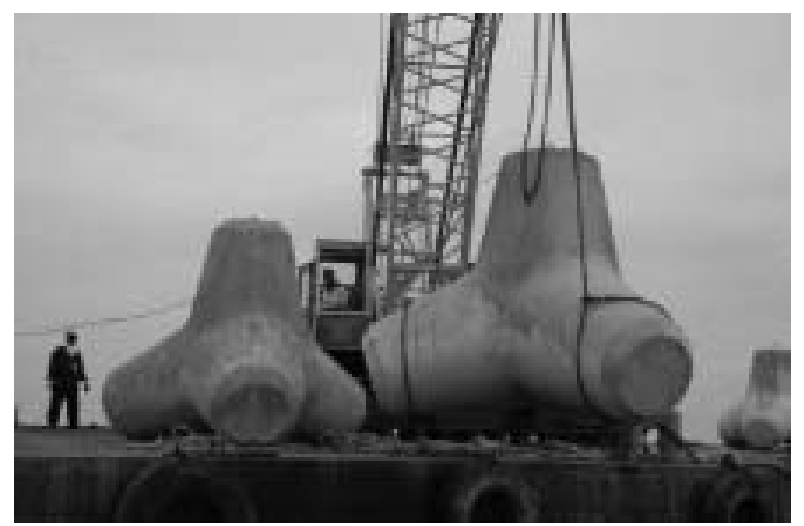

Figure 2-a. Tetrapods (2.65mx2.65mx2.65m), weight seven metric tonnes/module

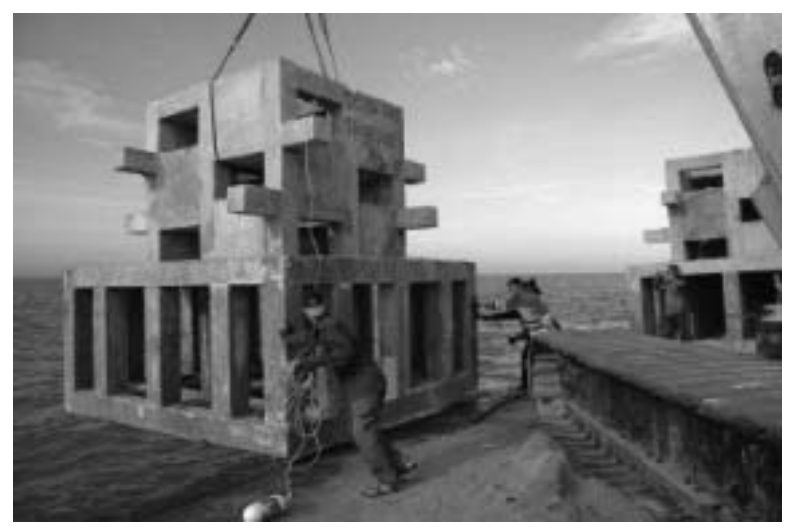

Figure 2-c. Soft bottom Anti-trawling (3.75mx3.75mx3.85m), weight 32 metric tonnes/module

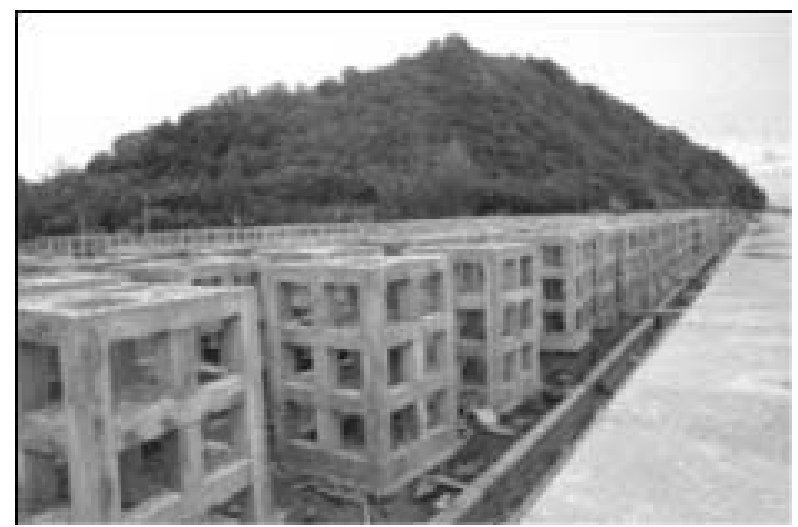

Figure 2-e. Cuboid (2.0mx2.0mx3.0m), weight 10 metric tonnes/module

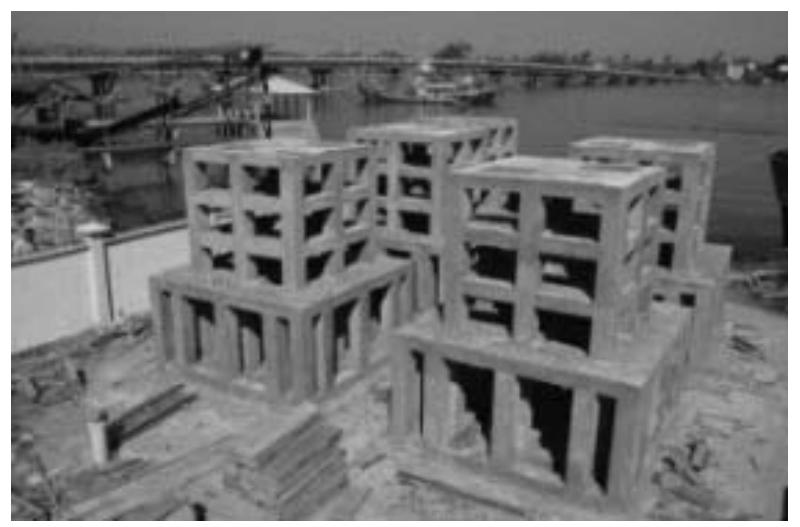

Figure 2-b. Soft bottom (3.75mx3.75mx3.85m), weight 23 metric tonnes/module

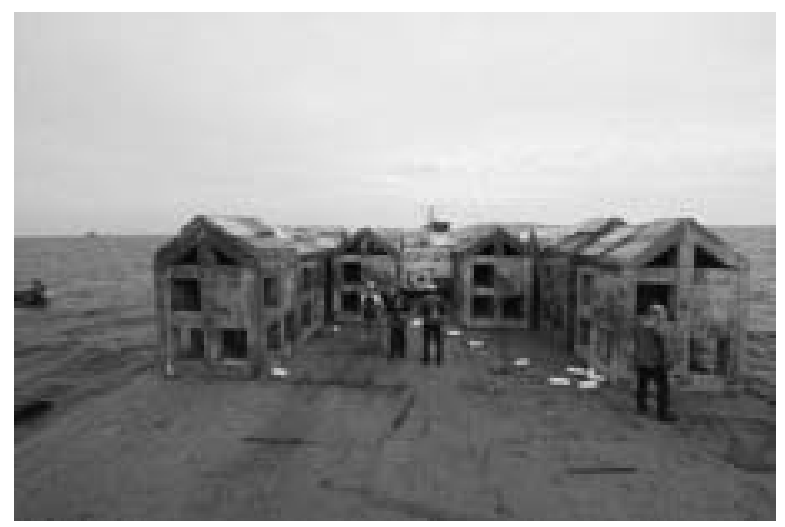

Figure 2-d. Cuboid bio-active (2.0mx2.0mx3.0m), weight 14 metric tonnes/module

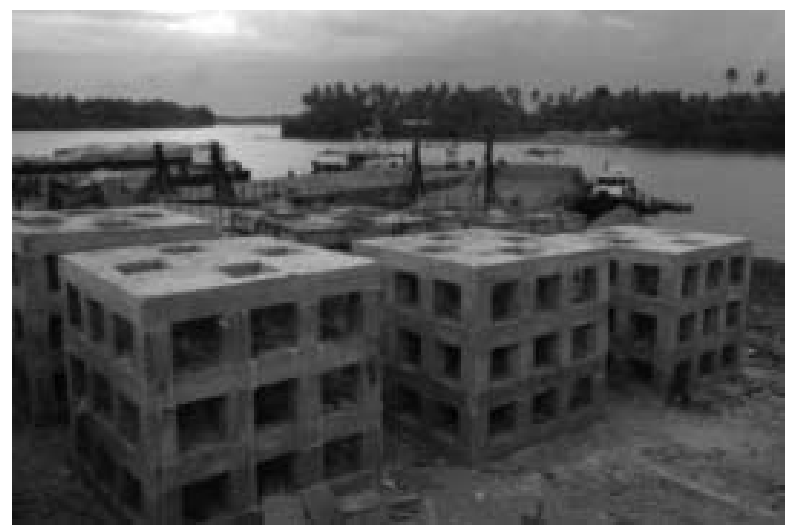

Figure 2-f . Cube (2.5mx2.5mx2.5m), weight 16 metric tonnes/ module 


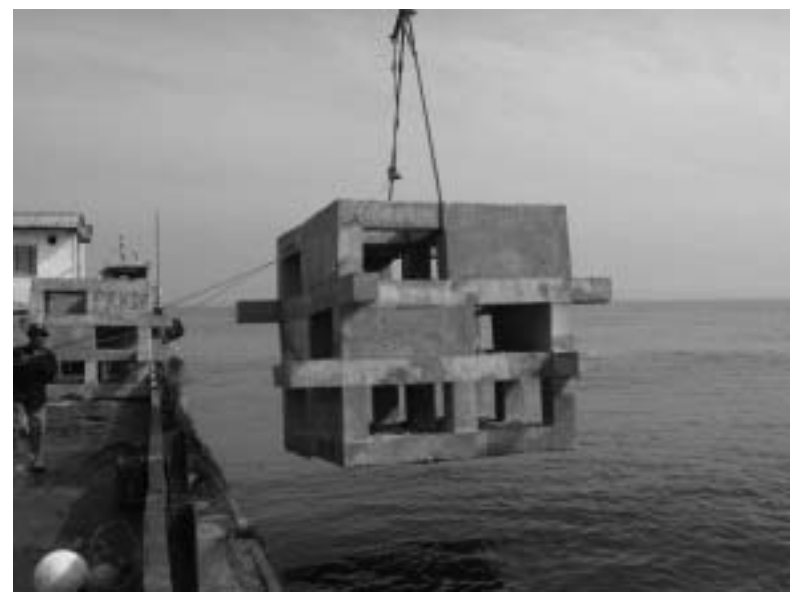

Figure 2-g. Cube Anti-Trawling (3.0mx3.0mx3.0m), weight 14.5 metric tonnes/module

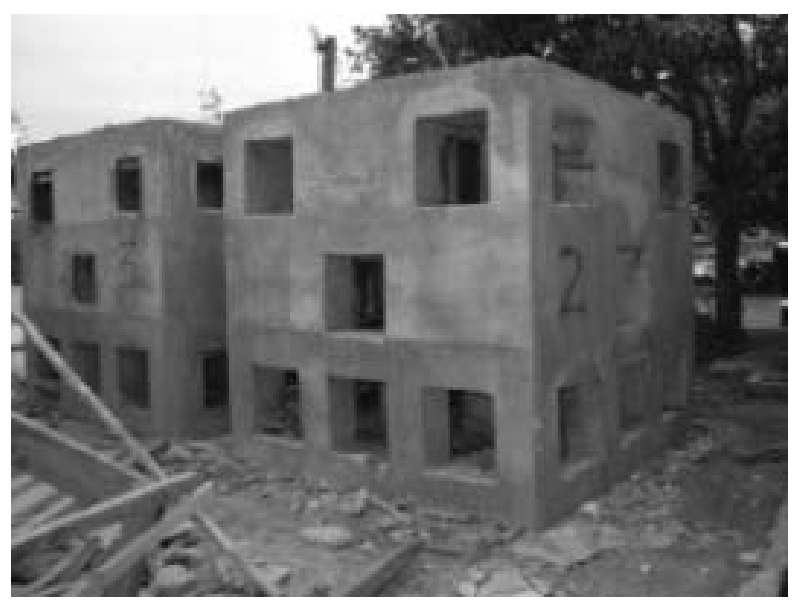

Figure 2-h. Cube juvenile (2.5mX2.5mX2.5m), weight 20 metric tonnes/module

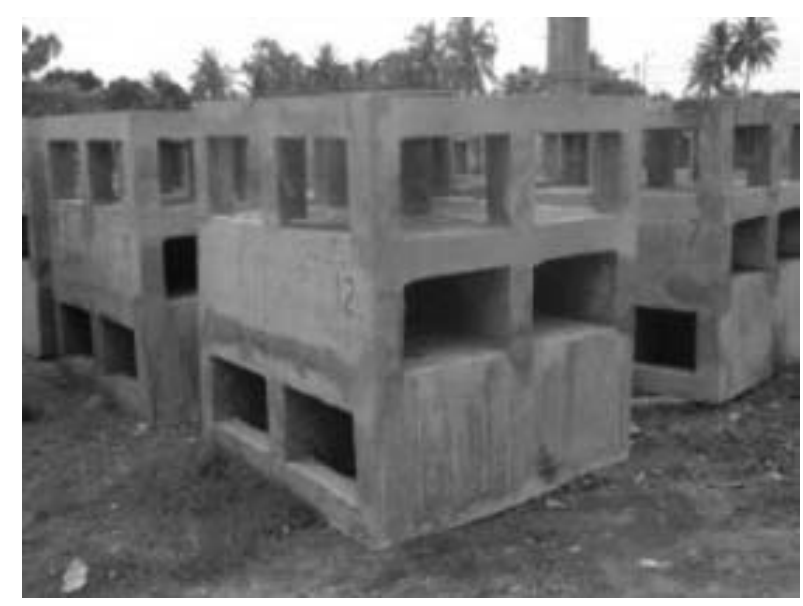

Figure 2-i. Lobster (1.65mx1.65mx1.65m), weight 5 metric tonnes/module.

Figure 2(a-i): Nine designs of big size ARs deployed in the east coast of Peninsular Malaysia 2006-2012 


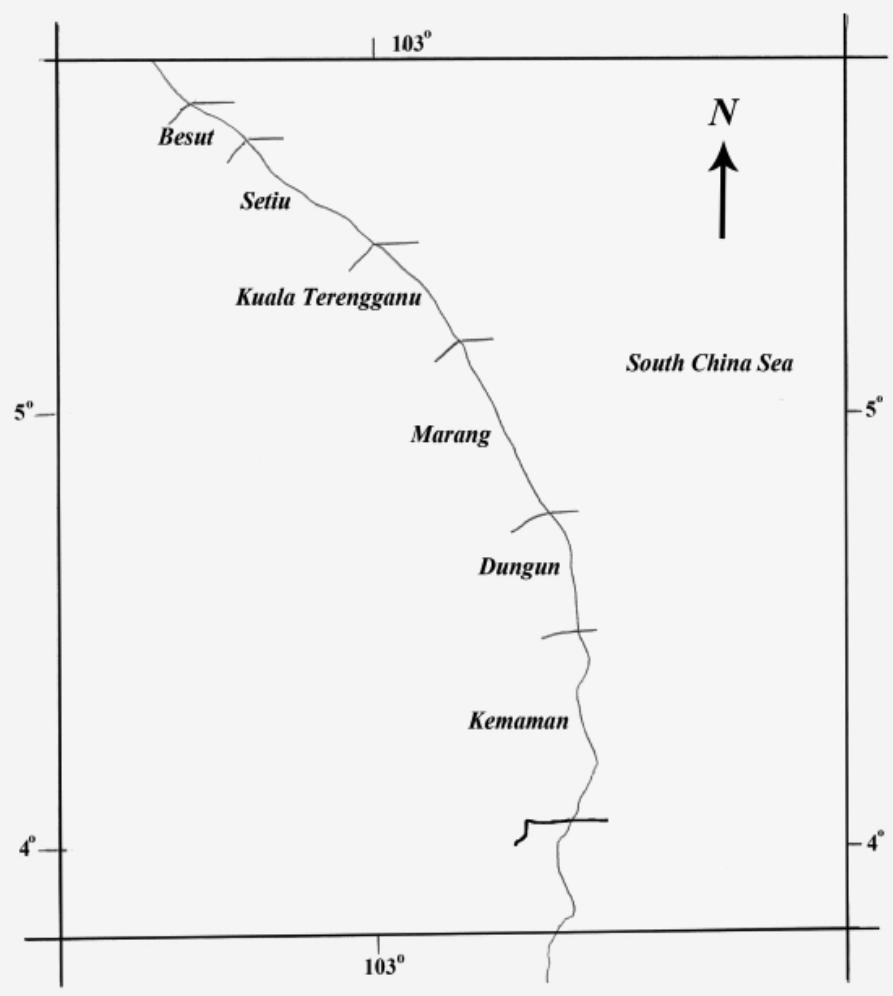

Figure 3. Locations of study sites in State of Terengganu (Setiu, Kuala Terengganu, Marang)

Table 1. Specification of big size ARs used in this study

\begin{tabular}{|c|c|c|c|c|c|c|c|}
\hline No & Name of ARs & $\begin{array}{l}\text { Type of } \\
\text { sediment at } \\
\text { deployed area }\end{array}$ & $\begin{array}{l}\text { Measurement (m) } \\
\text { (length x width x } \\
\text { height) }\end{array}$ & $\begin{array}{l}\text { Weight } \\
\text { (tonnes) }\end{array}$ & $\begin{array}{l}\text { Grade of } \\
\text { ready-mixed } \\
\text { concrete }\end{array}$ & $\begin{array}{l}\text { No of ARs/ } \\
\text { Site }\end{array}$ & $\begin{array}{l}\text { No of } \\
\text { Site }\end{array}$ \\
\hline 1 & Tetrapod & Sandy & $2.65 \times 2.65 \times 2.65$ & 7 & 40 & 17 & 12 \\
\hline 2 & Soft bottom & Muddy & $3.75 \times 3.75 \times 3.85$ & 23 & 50 & 14 & 8 \\
\hline 3 & Soft bottom Anti-trawling & Muddy & $3.75 \times 3.75 \times 3.85$ & 32 & 50 & 70 & 4 \\
\hline 4 & Cuboid Bioactive & Sandy & $2.0 \times 2.0 \times 3.0$ & 14 & 40 & 14 & 1 \\
\hline 5 & Cuboid & Sandy & $2.0 \times 2.0 \times 3.0$ & 10 & 40 & 128 & 4 \\
\hline 6 & Cube & Sandy & $2.5 \times 2.5 \times 2.5$ & 16 & 40 & 14 & 6 \\
\hline 7 & Cube Anti- trawling & Sandy & $3.0 \times 3.0 \times 3.0$ & 14.5 & 40 & 9 & 2 \\
\hline 8 & Cube juvenile & Sandy & $2.5 \times 2.5 \times 2.5$ & 20 & 40 & 14 & 1 \\
\hline 9 & Lobster & Sandy & $1.65 \times 1.65 \times 1.65$ & 5 & 40 & 40 & 1 \\
\hline & Total & & & & & & 39 \\
\hline
\end{tabular}


Table 2. Percentage cover of fouling organisms found on the surface of sampled Cuboid ARs at Setiu, Kuala Terengganu and Marang (6, 12, 24 months after deployment)

\begin{tabular}{|l|l|l|l|l|l|l|l|l|l|}
\hline & \multicolumn{3}{l}{ Setiu } & \multicolumn{3}{l|}{ Kuala Terengganu } & \multicolumn{2}{l|}{ Marang } \\
\hline Months after deployed & 6 & 12 & 24 & 6 & 12 & 24 & 6 & 12 & 24 \\
\hline Barnacle (\%) & 70 & 50 & 10 & 60 & 45 & 10 & 60 & 45 & 20 \\
\hline Bivalve (\%) & 10 & 15 & 10 & 10 & 20 & 30 & 20 & 25 & 30 \\
\hline Sponges (\%) & 10 & 15 & 5 & 20 & 20 & 10 & 10 & 10 & 10 \\
\hline Soft corals (\%) & 5 & 10 & 70 & 5 & 10 & 45 & 5 & 15 & 30 \\
\hline Others* & 5 & 10 & 5 & 5 & 5 & 5 & 5 & 5 & 10 \\
\hline
\end{tabular}

Others = Ascidians, algae, hard corals, etc.

Table 3. Number of fish enumerated at each site during First Phase (11-15 months) and Second Phase (36-45 months) after deployment of ARs at Setiu, Kuala Terengganu (K.Trg) and Marang

\begin{tabular}{|c|c|c|c|c|c|c|c|}
\hline \multirow[t]{2}{*}{ No } & \multirow[b]{2}{*}{ Location } & \multicolumn{3}{|c|}{ First Phase (2009) } & \multicolumn{3}{|c|}{ Second Phase (2010) } \\
\hline & & Setiu & K. Trg & Marang & Setiu & K.Trg & Marang \\
\hline & Month after deployment & 11 & 11 & 15 & 45 & 44 & 36 \\
\hline 1 & Atule mate & 0 & 350 & 0 & 0 & 0 & 0 \\
\hline 2 & Alepes djedaba & 0 & 0 & 0 & 0 & 350 & 0 \\
\hline 3 & Carangoides sp. & 0 & 125 & 0 & 0 & 500 & 0 \\
\hline 4 & Carangoides malabaricus & 0 & 8 & 0 & 0 & 0 & 0 \\
\hline 5 & Cephalopholis boenack & 3 & 7 & 6 & 3 & 8 & 3 \\
\hline 6 & Chiloscyllium griseum & 2 & 0 & 4 & 3 & 0 & 4 \\
\hline 7 & Diagramma pictum & 5 & 20 & 6 & 1 & 30 & 3 \\
\hline 8 & Epinephelus areolatus & 2 & 5 & 4 & 4 & 6 & 2 \\
\hline 9 & Epinephelus coioides & 1 & 2 & 0 & 0 & 2 & 1 \\
\hline 10 & Lutjanus lutjanus & 500 & 2000 & 1500 & 300 & 700 & 500 \\
\hline 11 & Lutjanus vitta & 60 & 200 & 50 & 50 & 100 & 200 \\
\hline 12 & Lutjanus sebae & 0 & 3 & 0 & 0 & 0 & 0 \\
\hline 13 & Lutjanus quinquelineatus & 0 & 0 & 0 & 0 & 0 & 70 \\
\hline 14 & Lutjanus erythropterus & 0 & 0 & 1 & 0 & 0 & 0 \\
\hline 15 & Lutjanus russelli & 2 & 2 & 4 & 0 & 1 & 2 \\
\hline 16 & Panulirus ornatus & 0 & 0 & 1 & 0 & 0 & 0 \\
\hline 17 & Portunus sp. (Crab) & 1 & 1 & 1 & 0 & 1 & 1 \\
\hline 18 & Siganus guttatus & 5 & 7 & 3 & 7 & 12 & 0 \\
\hline \multirow[t]{3}{*}{19} & Siganus javus & 3 & 4 & 7 & 0 & 5 & 0 \\
\hline & Total species & 11 & 14 & 12 & 7 & 13 & 10 \\
\hline & Total fish & 584 & 2734 & 1587 & 368 & 1715 & 786 \\
\hline
\end{tabular}


Appendix 1. Checklist of common fauna and flora observed on the surface of sampled modules of Cuboid ARs at Setiu, Kuala Terengganu and Marang

\begin{tabular}{|c|c|c|c|c|}
\hline No. & Scientific name & Setiu & Kuala Terengganu & Marang \\
\hline & Class Echinoidea & $\checkmark$ & $\checkmark$ & $\checkmark$ \\
\hline 1 & Echinothrix calamaris & $\checkmark$ & $\checkmark$ & $\checkmark$ \\
\hline 2 & Echinoneus cyclostomus & $\checkmark$ & $\checkmark$ & $\checkmark$ \\
\hline \multirow[t]{2}{*}{3} & Echinodiscus tenuissismus & $\checkmark$ & $\mathrm{X}$ & $\mathrm{X}$ \\
\hline & Class Crinoidea & $\checkmark$ & $\checkmark$ & $\checkmark$ \\
\hline 4 & Comaster multibrachiatus & $\checkmark$ & $\checkmark$ & $\checkmark$ \\
\hline 5 & Comantheria sp. & $\checkmark$ & $\checkmark$ & $\checkmark$ \\
\hline \multirow[t]{2}{*}{6} & Lamprometra sp. & $\mathrm{X}$ & $\checkmark$ & $\checkmark$ \\
\hline & Class Holothuroidea & & & \\
\hline 7 & Stichopus cf horrens & $\checkmark$ & $\mathrm{X}$ & $\mathrm{X}$ \\
\hline 8 & Stichopus ocellatus & $\checkmark$ & $\checkmark$ & $\mathrm{X}$ \\
\hline 9 & Opheodesoma spectabilis & $\checkmark$ & $\checkmark$ & $\checkmark$ \\
\hline 10 & Holothuria ocellata & $\mathrm{X}$ & $\checkmark$ & $\checkmark$ \\
\hline 11 & Holothuria pardalis & $\mathrm{X}$ & $\mathrm{X}$ & $\checkmark$ \\
\hline 12 & Bohadschia marmorata & $\checkmark$ & $\mathrm{X}$ & $\mathrm{X}$ \\
\hline \multirow[t]{2}{*}{13} & Euapta sp. & $\checkmark$ & $\checkmark$ & $\checkmark$ \\
\hline & Class Anthozoa & $\checkmark$ & $\checkmark$ & $\checkmark$ \\
\hline 14 & Acabaria sp. & $\checkmark$ & $\mathrm{X}$ & $\mathrm{X}$ \\
\hline 15 & Melithaea sp. & $\checkmark$ & $\mathrm{X}$ & $\mathrm{X}$ \\
\hline 16 & Subergorgia sp. & $\checkmark$ & $\checkmark$ & \\
\hline 17 & Scytalium sp. & $\checkmark$ & $\mathrm{X}$ & $\mathrm{X}$ \\
\hline 18 & Scleronephthya sp. & $\checkmark$ & $\checkmark$ & $\checkmark$ \\
\hline 19 & Rumphella sp. & $\checkmark$ & $\checkmark$ & $\checkmark$ \\
\hline 20 & Arachnanthus sp. & $\mathrm{X}$ & $\checkmark$ & $\checkmark$ \\
\hline 21 & Acalycigorgia sp. & $\checkmark$ & $\checkmark$ & $\checkmark$ \\
\hline 22 & Cerianthus filiformis & $\checkmark$ & $\checkmark$ & $\checkmark$ \\
\hline 23 & Cerianthus sp. & $\checkmark$ & $\checkmark$ & $\checkmark$ \\
\hline 24 & Condylactis gigantea & $\checkmark$ & $\checkmark$ & $\checkmark$ \\
\hline 25 & Cirripathes sp. & $\checkmark$ & $\checkmark$ & $\checkmark$ \\
\hline \multirow[t]{2}{*}{26} & Dendronephthya sp. & $\checkmark$ & $\checkmark$ & $\checkmark$ \\
\hline & Class Gastropoda & $\checkmark$ & $\checkmark$ & $\checkmark$ \\
\hline 27 & Chicoreus sp. & $\checkmark$ & $\checkmark$ & $\checkmark$ \\
\hline 28 & Ceratosoma trilobatum & $\checkmark$ & $\checkmark$ & $\checkmark$ \\
\hline 29 & Chromodoris sp. & $\checkmark$ & $\checkmark$ & $\checkmark$ \\
\hline
\end{tabular}




\begin{tabular}{|c|c|c|c|c|}
\hline 30 & Gymnodoris rubropapilosa & $\checkmark$ & $\checkmark$ & $\checkmark$ \\
\hline 31 & Pteraeolidia sp. & $\checkmark$ & $\checkmark$ & $\checkmark$ \\
\hline 32 & Pteraeolidia ianthina & $\checkmark$ & $\checkmark$ & $\checkmark$ \\
\hline 33 & Nassarius sp. & $\checkmark$ & $\checkmark$ & $\checkmark$ \\
\hline 34 & Nembrotha lineolata & $\checkmark$ & $\checkmark$ & $\checkmark$ \\
\hline \multirow[t]{2}{*}{35} & Risbecia tryoni & $\checkmark$ & $\checkmark$ & $\checkmark$ \\
\hline & Class Calcarea & $\checkmark$ & $\checkmark$ & $\checkmark$ \\
\hline 36 & Callyspongia sp. & $\checkmark$ & $\checkmark$ & $\checkmark$ \\
\hline 37 & Haliclona sp. & $\checkmark$ & $\checkmark$ & $\checkmark$ \\
\hline \multirow[t]{2}{*}{38} & Plakortis sp. & $\checkmark$ & $\checkmark$ & $\checkmark$ \\
\hline & Class Hydrozoa & $\checkmark$ & $\checkmark$ & $\checkmark$ \\
\hline 39 & Gymnangium gracilicaule & $\checkmark$ & $\checkmark$ & $\checkmark$ \\
\hline \multirow[t]{2}{*}{40} & Macrorhynchia philippina & $\checkmark$ & $\checkmark$ & $\checkmark$ \\
\hline & Class Bryosidophyceae & $\checkmark$ & $\checkmark$ & $\checkmark$ \\
\hline 41 & Halimeda sp. & $\checkmark$ & $\mathrm{X}$ & $\mathrm{X}$ \\
\hline \multirow[t]{2}{*}{42} & Halophila ovalis & $\checkmark$ & $\checkmark$ & $\checkmark$ \\
\hline & Class Mollusca & $\checkmark$ & $\checkmark$ & $\checkmark$ \\
\hline 43 & Isognomon sp. & $\checkmark$ & $\checkmark$ & $\checkmark$ \\
\hline 44 & Ostrea sp. & $\checkmark$ & $\checkmark$ & $\checkmark$ \\
\hline 45 & Pinctada margaritifera & $\checkmark$ & $\checkmark$ & $\checkmark$ \\
\hline 46 & Pinctada fucata & $\checkmark$ & $\checkmark$ & $\checkmark$ \\
\hline 47 & Pinctada sp. & $\checkmark$ & $\checkmark$ & $\checkmark$ \\
\hline 48 & Pinna sp. & $\checkmark$ & $\checkmark$ & $\checkmark$ \\
\hline 49 & Pteria penguin & $\checkmark$ & $\checkmark$ & $\checkmark$ \\
\hline 50 & Spondylus spp. & $\checkmark$ & $\checkmark$ & $\checkmark$ \\
\hline
\end{tabular}

Appendix 2. Checklist of fish, crab, squid and lobster species recorded at ARs locations during the study period

\begin{tabular}{|l|l|l|l|}
\hline No & Scientific name & $\begin{array}{l}\text { Source of } \\
\text { Information* }\end{array}$ & Locations of ARs \\
\hline & Family Carangidae (1) & & \\
\hline 1 & Alepes djedaba & 1,3 & Terengganu, Kelantan and Pahang \\
\hline 2 & Atule mate & $1,2,3$ & Terengganu, Kelantan, Pahang and Johor \\
\hline 3 & Carangoides bajad & $1,2,3$ & Terengganu, Kelantan and Pahang \\
\hline 4 & Carangoides malabaricus & 1,3 & Terengganu, Kelantan and Pahang \\
\hline 5 & Caranx sexfasciatus & 3 & Terengganu, Kelantan and Pahang \\
\hline 6 & Decapterus macrosoma & 3 & Terengganu, Kelantan \\
\hline 7 & Decapterus maruadsi & 3 & Terengganu, Kelantan \\
\hline
\end{tabular}




\begin{tabular}{|c|c|c|c|}
\hline 8 & Gnathanodon speciosus & 1 & Terengganu \\
\hline \multirow[t]{2}{*}{9} & Megalaspis cordyla & 2,3 & Terengganu, Kelantan \\
\hline & Family Serranidae (2) & & \\
\hline 10 & Anyperodon leucogrammicus & 1 & Terengganu \\
\hline 11 & Cephalopholis boenack & $1,2,3$ & Terengganu, Kelantan, Pahang and Johor \\
\hline 12 & Cephalopholis formosa & 1 & Terengganu \\
\hline 13 & Epinephelus amblycephalus & 1 & Terengganu \\
\hline 14 & Epinephelus areolatus & $1,2,3$ & Terengganu, Kelantan, Pahang and Johor \\
\hline 15 & Epinephelus bleekeri & 1,3 & Terengganu, Kelantan, Pahang and Johor \\
\hline 16 & Epinephelus coioides & 1 & Terengganu \\
\hline 17 & Epinephelus malabaricus & 1,3 & Terengganu, Kelantan, Pahang and Johor \\
\hline \multirow[t]{2}{*}{18} & Epinephelus sexfasciatus & 1,3 & Terengganu \\
\hline & Family Scyliorhinidae (3) & & \\
\hline \multirow[t]{2}{*}{19} & Atelomycterus marmoratus & 1 & Terengganu \\
\hline & Family Caesionidae (4) & & \\
\hline 20 & Caesio cunning & 1,3 & Kelantan, Terengganu \\
\hline 21 & Caesio teres & 1,3 & Kelantan, Terengganu \\
\hline 22 & Pterocaesio chrysozona & 1,3 & Terengganu, Kelantan, Pahang and Johor \\
\hline \multirow[t]{2}{*}{23} & Pterocaesio diagramma & 1,3 & Terengganu, Kelantan, Pahang and Johor \\
\hline & Family Portunidae (5) & & \\
\hline 24 & Charybdis feriatus & 1 & Terengganu \\
\hline 25 & Charybdis natator & 1 & Terengganu \\
\hline \multirow[t]{2}{*}{26} & Portunus sp. & 1 & Terengganu \\
\hline & Family Hemiscyllidae (6) & & \\
\hline \multirow[t]{2}{*}{27} & Chiloscyllium griseum & 1 & Terengganu, Pahang \\
\hline & Family Haemulidae (7) & & \\
\hline 28 & Diagramma pictum & $1,2,3$ & Terengganu, Kelantan, Pahang and Johor \\
\hline \multirow[t]{2}{*}{29} & Plectorhinchus gibbosus & $1,2,3$ & Terengganu, Kelantan, Pahang and Johor \\
\hline & Family Muraenidae (8) & & \\
\hline 30 & Gymnothorax fimbriatus & 1 & Terengganu \\
\hline 31 & Gymnothorax javanicus & 1 & Terengganu \\
\hline 32 & Gymnothorax reevesii & 1 & Terengganu \\
\hline \multirow[t]{2}{*}{33} & Gymnothorax thyrsoideus & 1,2 & Terengganu \\
\hline & Family Dasyatidae (9) & & \\
\hline 34 & Himantura jenskinsii & 1 & Terengganu \\
\hline 35 & Himantura gerradi & 1 & Terengganu \\
\hline 36 & Himantura uarnak & 1 & Terengganu \\
\hline 37 & Pastinachus sephen & 1 & Pahang \\
\hline \multirow[t]{2}{*}{38} & Taeniura mayeni & 1 & Pahang \\
\hline & Family Leiognatidae (10) & & \\
\hline \multirow[t]{2}{*}{39} & Leiognathus sp & 1 & Terengganu \\
\hline & Family Lethrinidae (11) & & \\
\hline
\end{tabular}




\begin{tabular}{|c|c|c|c|}
\hline 40 & Lethrinus lentjan & 1 & Terengganu \\
\hline \multirow[t]{2}{*}{41} & Lethrinus microdon & 1 & Terengganu \\
\hline & Family Lutjanidae (12) & & \\
\hline 42 & Lutjanus argentimaculatus & 1 & Terengganu \\
\hline 43 & Lutjanus erythropterus & 1 & Johor \\
\hline 44 & Lutjanus fulviflamma & 1 & Terengganu \\
\hline 45 & Lutjanus johnii & 1,3 & Terengganu, Kelantan, Pahang and Johor \\
\hline 46 & Lutjanus kasmira & 1 & Terengganu \\
\hline 47 & Lutjanus lutjanus & $1,2,3$ & Terengganu, Kelantan, Pahang and Johor \\
\hline 48 & Lutjanus russellii & 1,3 & Terengganu, Kelantan, Pahang and Johor \\
\hline 49 & Lutjanus malabaricus & 1,3 & Terengganu \\
\hline 50 & Lutjanus monostigma & 1 & Terengganu, Johor \\
\hline 51 & Lutjanus sebae & 1,3 & Terengganu \\
\hline 52 & Lutjanus quinquelineatus & 1 & Kelantan, Terengganu, Johor \\
\hline 53 & Lutjanus vitta & $1,2,3$ & Terengganu, Kelantan, Pahang and Johor \\
\hline \multirow[t]{2}{*}{54} & Pinjalo pinjalo & 1 & Terengganu \\
\hline & Family Monacanthidae (13) & & \\
\hline \multirow[t]{2}{*}{55} & Monacanthus chinensis & 1 & Terengganu \\
\hline & Family Mullidae (14) & & \\
\hline 56 & Mulloidichthys flavolineatus & 1 & Terengganu \\
\hline \multirow[t]{2}{*}{57} & Upeneus tragula & 1 & Terengganu \\
\hline & Family Nemipteridae (15) & & \\
\hline 58 & Nemipterus peronii & 2,3 & Terengganu, Kelantan, Pahang \\
\hline 59 & Pentapodus nagasakiensis & 1,3 & Terengganu, Kelantan, Pahang \\
\hline 60 & Pentapodus setosus & 1,3 & Terengganu, Kelantan, Pahang \\
\hline \multirow[t]{2}{*}{61} & Scolopsis vosmeri & 1 & Terengganu \\
\hline & Family Palinuridae (16) & & \\
\hline \multirow[t]{2}{*}{62} & Panulirus polyphagus & 1 & Johor, Terengganu \\
\hline & Family Ephippidae (17) & & \\
\hline \multirow[t]{2}{*}{63} & Platax teira & 1 & Terengganu, Johor \\
\hline & Family Plotosidae (18) & & \\
\hline \multirow[t]{2}{*}{64} & Plotosus sp & 1 & Terengganu \\
\hline & Family Paralichthyidae (19) & & \\
\hline \multirow[t]{2}{*}{65} & Pseudorhombus pentophalmus & 1 & Terengganu \\
\hline & Family Rachycentridae (20) & & \\
\hline \multirow[t]{2}{*}{66} & Rachycentron canadum & 1,3 & Terengganu, Kelantan, Pahang and Johor \\
\hline & Family Scombridae (21) & & \\
\hline \multirow[t]{2}{*}{67} & Rastrellinger kanagurta & 2,3 & Terengganu, Kelantan, Pahang and Johor \\
\hline & Family Sepiidae (22) & & \\
\hline \multirow[t]{2}{*}{68} & Sepia pharonis & 1 & Terengganu \\
\hline & Family Loliginidae (23) & & \\
\hline 69 & Loligo chinensis & 2,3 & Terengganu, Kelantan, Pahang and Johor \\
\hline
\end{tabular}




\begin{tabular}{|c|c|c|c|}
\hline 70 & Sepioteuthis lessoniana & 2,3 & Kelantan, Terengganu \\
\hline & Family Scaridae (24) & & \\
\hline \multirow[t]{2}{*}{71} & Scarus psittacus & 1 & Terengganu \\
\hline & Family Siganidae (25) & & \\
\hline 72 & Siganus canaliculatus & $1,2,3$ & Terengganu, Kelantan \\
\hline 73 & Siganus guttatus & $1,2,3$ & Terengganu, Kelantan \\
\hline \multirow[t]{2}{*}{74} & Siganus javus & $1,2,3$ & Terengganu, Kelantan \\
\hline & Family Sphyraenidae (26) & & \\
\hline 75 & Sphyraena jello & $1,2,3$ & Terengganu, Kelantan \\
\hline \multirow[t]{2}{*}{76} & Sphyraena obtusata & 1 & Terengganu \\
\hline & Family Terapontidae (27) & & \\
\hline \multirow[t]{2}{*}{77} & Terapon jarbua & 2,3 & Terengganu, Kelantan \\
\hline & Family Centriscidae (28) & & \\
\hline \multirow[t]{2}{*}{78} & Centristcus scutatus & 1 & Terengganu \\
\hline & Family Gobiidae (29) & & \\
\hline 79 & Amblyeleotris rubrimarginata & 1 & Terengganu \\
\hline \multirow[t]{2}{*}{80} & Fusigobius inframaculatus & 1 & Terengganu \\
\hline & Family Pomacentridae (30) & & \\
\hline 81 & Amphiprion polymnus & 1 & Terengganu \\
\hline 82 & Centropyge multifasciatus & 1 & Terengganu \\
\hline 83 & Neopomacentrus azystron & 1 & Terengganu \\
\hline 84 & Neopomacentrus cyanomos & 1 & Terengganu \\
\hline 85 & Pomacanthus annularis & 1 & Terengganu \\
\hline \multirow[t]{2}{*}{86} & Pomacentrus milleri & 1 & Terengganu \\
\hline & Family Antennariidae (31) & & \\
\hline \multirow[t]{2}{*}{87} & Antennarius sp & 1 & Terengganu \\
\hline & Family Apogonidae (32) & & \\
\hline 88 & Apogon aureus & 1 & Terengganu \\
\hline 89 & Apogon cavitiensis & 1 & Terengganu \\
\hline 90 & Apogon endekataenia & 1 & Terengganu \\
\hline 91 & Apogon nigrocincta & 1 & Terengganu \\
\hline 92 & Archamia fucata & 1 & Terengganu \\
\hline \multirow[t]{2}{*}{93} & Cheilodipterus quinquelineatus & 1 & Terengganu \\
\hline & Family Tetraodontidae (33) & & \\
\hline 94 & Arothron hispidus & 1 & Terengganu \\
\hline 95 & Arothron immaculatus & 1 & Terengganu \\
\hline 96 & Arothron manilensis & 1 & Terengganu \\
\hline 97 & Arothron mappa & 1 & Terengganu \\
\hline 98 & Arothron stellatus & 1,2 & Terengganu \\
\hline \multirow[t]{2}{*}{99} & Sphoeroides pachygaster & 1 & Terengganu \\
\hline & Family Chaetodontidae (34) & & \\
\hline 100 & Chelmon rostratus & 1 & Terengganu \\
\hline
\end{tabular}




\begin{tabular}{|l|l|l|l|}
\hline & Family Diodontidae (35) & & \\
\hline 101 & Diodon holocanthus & 1,2 & Terengganu \\
\hline 102 & Diodon hystrix & 1 & Terengganu \\
\hline 103 & Diodon liturosus & 1 & Terengganu \\
\hline & Family Chaetodontidae (36) & & \\
\hline 103 & Heniochus acuminatus & 1 & Terengganu, Johor \\
\hline & Family Labridae (37) & & \\
\hline 104 & Labroides dimidiatus & 1 & Terengganu \\
\hline & Family Ostraciidae (38) & & \\
\hline 105 & Ostracion cubicus & 1 & Terengganu \\
\hline 106 & Ostracion nasus & 1 & Terengganu \\
\hline & Family Scorpaenidae (39) & & \\
\hline 107 & Pterois ruselli & 1 & Terengganu \\
\hline 108 & Pterois volitans & 1 & Terengganu \\
\hline & Family Holocentridae (40) & & \\
\hline 109 & Sargocentrum rubrum & 1 & Terengganu \\
\hline
\end{tabular}

\footnotetext{
*1= Identified during SCUBA, from video and photos

2= Fish captured by DoFM researchers using hook and lines

3= Information gathered from face-to-face interviews with traditional fishermen
} 
Malaysian Journal of Science 32 (SCS Sp Issue) : 19-36 (2013) 